\title{
INFLUENCE OF THE SHOOT DENSITY OF Halodule wrightii ASCHERSON FROM ROCKY AND SANDY HABITATS ON ASSOCIATED MACROALGAL COMMUNITIES
}

\author{
Kcrishna Vilanova de Souza Barros ${ }^{1}$, *, Caroline Feijão Ximenes ${ }^{I}$, Pedro Bastos Macedo Carneiro ${ }^{\text {, }}$, \\ Cristina de Almeida Rocha-Barreiral ${ }^{1}$ and Karine Matos Magalhães ${ }^{2}$ \\ ${ }^{1}$ Universidade Federal do Ceará - Instituto de Ciências do Mar (Labomar/UFC) \\ (Av. Abolição, 3207 60165-081 Fortaleza, CE, Brasil) \\ ${ }^{2}$ Universidade Federal Rural de Pernambuco - Laboratório de Ecossistemas Aquáticos (LEAqua/UFRPE) \\ (Rua Dom Manoel de Medeiros, s/n 52171-900 Recife, PE, Brasil) \\ *Corresponding author: kcrishna@gmail.com
}

\begin{abstract}
A B S T R A C T
This study evaluated the influence of the shoot density of the shoal grass Halodule wrightii on the composition of the associated algal community, in rocky and sandy habitats on the coast of Ceará in northeastern Brazil. The phycological community included 18 species in 10 families, members of Rodophyta (72.2\%), Chlorophyta (22.2\%) and Phaeophyceae (5.5\%). The largest proportion were epilithic (50\%), followed by epiphytes on $\mathrm{H}$. wrightii (38.4\%), epipsammics (8\%), and epiphytes on other algae (4\%). Epiphytes on $\mathrm{H}$. wrightii occurred mainly associated with rhizomes, but also tendrils of $\mathrm{H}$. musciformis occurred attached to the leaves. The phycological community varied according to the density of $\mathrm{H}$. wrightii, independently of particular characters of the meadows, although both habitat and other environmental variables seemed to influence the macroalgae composition and diversity. The rocky habitat was more diverse than the sandy habitat, but in the sandy habitat the shoal grass was important for algal settlement in areas where hard substrates were scarce or absent.
\end{abstract}

\section{RESUMO}

Este estudo avaliou a influência da densidade do capim-agulha Halodule wrightii sobre a composição da comunidade algal associada, em habitats rochosos e arenosos da costa do Ceará, Nordeste do Brasil. A comunidade ficológica incluiu 18 espécies em de 10 famílias, integrantes de Rodophyta (72.2\%), Chlorophyta (22.2\%) e Phaeophyceae (5.5\%). A maior proporção foi epilítica (50\%), seguida pelas epífitas de $H$. wrightii $(38.4 \%)$, epífitas de outras algas (8\%) e epipsâmicas (4\%). Epífitas de $H$. wrightii ocorreram associadas com os rizomas, mas gavinhas de $H$. musciformis ocorreram presas às folhas. A comunidade ficológica variou de acordo com a densidade de $H$. wrightii independentemente das características particulares dos prados estudados, embora tanto o habitat quanto outras variáveis ambientais pareceram influenciar a composição e diversidade das macroalgas. O habitat rochoso foi mais diverso que o arenoso, mas no habitat arenoso o capimagulha foi importante para o assentamento de algas em áreas onde substratos duros foram raros ou ausentes.

Descriptors: Northeastern Brazil, Shoal grass, Seaweeds, Habit, Ecological relationships, Hypnea musciformis.

Descritores: Nordeste do Brasil, Capim-agulha, Macroalgas, Hábito, Relações ecológicas, Hypnea musciformis.

\section{INTRODUCTION}

Algae can be found in association with other biological systems, especially coral reefs (HAY, 1981; SILVA et al., 1987), mussel beds (ALBRECHT, 1998), and seagrass meadows (ZIEMAN; ZIEMAN, 1989; BOROWITZKA et al., 2006). Both positive and negative effects of seagrass-algae relationships are reported in the literature (SAND-JENSEN, 1977;
SILBERSTEIN et al., 1986; WILLIAMS, 1990; CECCHERELLI; CINELLI, 1997， 1998， 1999; SILVA; ASMUS, 2001; BRUN et al., 2003; TAPLIN et al., 2005; STAFFORD; BELL, 2006; PERGENT et al., 2008). In general, the combination of macroalgae and seagrasses may, to some extent, increase the area available for colonization, increasing food retention and shelter for fauna, and enhancing the productivity of the coastal environment (MAZZELLA; ALBERTE, 
1985; ZIEMAN; ZIEMAN, 1989; VIRNSTEIN; CARBONARA, 1985; NORKKO et al., 2000; WILLIAMS; HECK, 2001; BOROWITZKA et al., 2006; ROSA; BEMVENUTI, 2007).

Most studies on algae associated with seagrasses have focused on species composition (HAY, 1981; PEDRINI; SILVEIRA, 1985; SILVA et al., 1987; PEDRINI et al., 1997; PAULA et al., 2003; BARRIOS; DÍAZ, 2005), biomass (PEDRINI; SILVEIRA, 1985; SILVA et al., 1987; PAULA et al., 2003), spatial distribution (SILVA et al., 1987; PAULA et al., 2003; PEDRINI et al., 1997) and temporal distribution (PEDRINI et al., 1997) of macroalgae attached to seagrasses (PEDRINI; SILVEIRA, 1985; SILVA et al., 1987; PEDRINI et al., 1997; HAYS, 2005) or co-habitants (HAY, 1981; PAULA et al., 2003). Other studies have observed the habit of the algae on seagrasses (BIBER et al., 2004), trophic interactions (BOROWITZKA et al., 1990; LEPOINT et al., 2000; HAYS, 2005) or environmental influences on the seagrass-algae complex (PLUS et al. 2001).

However, the importance of biotic and abiotic factors controlling the distribution and abundance of the macroalgal components of the seagrass ecosystem is still largely unknown (BIBER et al., 2004). The effects of morphological characters of seagrasses, such as canopy (LEE et al., 2001) and shoot density (CECCHERELLI; CINELLI, 1997, 1998, 1999) on variations of algal populations are still rarely investigated. Likewise, relationships among seaweeds at the community level, and morphological variations of seagrasses are also poorly explored.

Both seagrass parts and morphological differences among the species provide structurally and temporally different habitats for colonization by epiphytes (BOROWITZKA; LETHBRIDGE, 1989; BOROWITZKA et al., 1990; LELIAERT et al., 2001; LAVERY; VANDERKLIFT, 2002). Furthermore, seagrasses have morphological plasticity related to seasonal and spatial changes (MARBÀ et al., 2004). Thus, variations of the shoot density may play an essential role in the algal community distributions as well as the establishment and retention of species, varying among seasons and habitats.

In addition to shoot density, the habitat where the meadows are established may be another important factor to determine features of the associated phycological communities. Bandeira (2002) hypothesized that seagrasses as well as epiphytic coverage may show different patterns according to substrate (i.e. rocky or sandy habitat). In addition, BOROWITZKA et al. (1990) suggested that seagrass habitat may increase the variations in species composition and abundance of the epiphytic organisms. According to Balata et al. (2007), some important issues concern understanding patterns of large-scale variability of algal assemblages, and in particular the discrimination between scale-dependent patterns and those due to differences among the habitats where the seagrasses grow.

The aim of this study was to analyze influences of the shoot density of Halodule wrightii Ascherson established on rocky and sandy habitats, on the composition of the associated phycological communities. Ecological relationships among algae and seagrasses were also observed.

\section{Material and Methods}

\section{Study Area}

The study was performed on two rocky beaches and two sandy beaches located on the coast of Ceará in northeastern Brazil (Fig. 1).

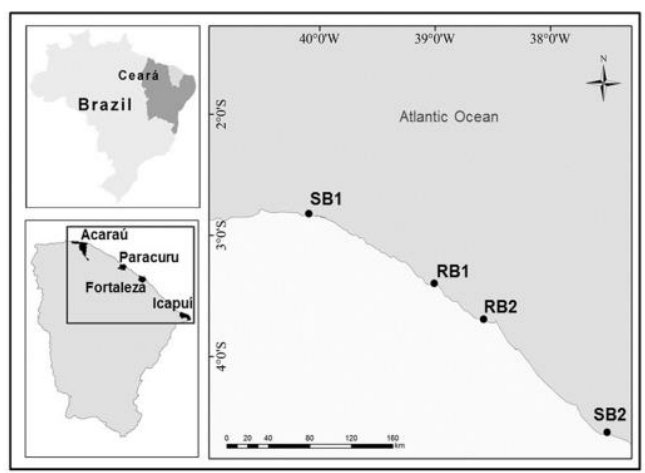

Fig. 1. Study sites located on the Ceará coast in northeastern Brazil. Legend: SB1 - Sandy Beach1, Arpoeiras Beach; RB1 - Rocky Beach1, Pedra Rachada Beach; RB2 - Rocky Beach2, Goiabeiras Beach; SB2 - Sandy Beach2, Ponta Grossa Beach

The local climate is defined as dry tropical, type Aw' (KÖPPEN, 1948), with low wind speeds in the rainy months, from February to May. In the following months, wind speeds progressively increase and reach their maximum from August to November, affecting the entire coastal zone (MORAIS, 1980; MORAIS et al., 2006; CASTELO BRANCO et al., 2001; CARVALHO et al., 2007).

According to Morais et al. (2006), the area is bordered by the saline and well-oxygenated waters of the North Brazil Current (NBC), which is partly responsible for the northwesterly direction of the coastal currents, whereas the longitudinal currents are primarily derived from trade winds and incidence of the waves on the coastline. Also based on these authors, the local tidal regime of this region is semidiurnal mesotidal, and the waves vary among the quadrants E, E-NE and E-SE, with periods between 4 and $7 \mathrm{~s}$, and wave height from 0.8 to $1.5 \mathrm{~m}$. 
All the study sites are subject to the same climatic influences, but have other distinct characteristics:

- Arpoeiras Beach (02\%49'09'S; 4005'43”W) Sandy Beach 1 (SB1): Dissipative. This beach has up to $2 \mathrm{~km}$ of bottom area exposed during low spring tides.

- Ponta Grossa Beach (04³7'33.8'S; 37³0'36.6”W) - Sandy Beach 2 (SB2): Dissipative, with intermittent rocky outcrops (beach rocks).

- Pedra Rachada Beach (03²3'45.6”S; 3900'32.2'W) - Rocky Beach 1 (RB1): Reef rocks belonging to the Barreiras formation are present. A vertical barrier of reefs shelters the meadow area especially during low spring tides.

- Goiabeiras Beach (03\%41'31'S; 038³4'49”W) Rocky Beach 2 (RB2): This seagrass bed is the most heavily impacted by human activities and hydrodynamic effects. Although the seagrass shoot density was not obtained for this site, this beach was included in this paper in order to extend the analysis.

\section{Sampling and Laboratory Procedures}

The sampling procedure was adapted from Burdick and Kendrick (2001), following suggestions for seagrass meadows with a high degree of patchiness. The sampling design included one point of origin (I, II and III) with the presence of $H$. wrightii and four replicates, $10 \mathrm{~m}$ distant from the point of origin, oriented according to the four cardinal points $(\mathrm{N}, \mathrm{S}, \mathrm{E}$ and $\mathrm{W})$. A total of 15 samples were taken in each season (dry and rainy), in 2010. The samples were taken with a PVC corer $(10 \mathrm{~cm}$ diameter $)$ inserted in the sediment to a depth of $10 \mathrm{~cm}$. The samples were washed with seawater, bagged, and tagged.

At the Institute of Marine Sciences, Federal University of Ceará (Instituto de Ciências do Mar, Universidade Federal do Ceará), macroalgae were identified, and the seagrass shoot density ( macroalgae abundance, and frequency of occurrence were calculated for each site. The algal species were also classified according to the habit as epilithic, epiphytic on seagrass, epiphytic on another alga, or epipsammic. The samples of algae were dried at $60^{\circ} \mathrm{C}$ for $24 \mathrm{~h}$ in order to obtain the biomass in grams of dry weight per square meter $\left(\mathrm{g} \mathrm{dw} \mathrm{m}^{-2}\right)$.

\section{Statistical Analyses}

Community descriptors, i.e. Shannon's diversity (H', $\log$ e), Pielou's evenness (J'), and Margalef's richness (d), were calculated for each site. Multi-dimensional Scaling (MDS) was applied in order to evaluate similarities among the sites. Community descriptors and MDS were obtained using the program Primer (Plymouth Routines in Multivariate Ecological Research), version 6.1.6.

Comparison between averages were performed according to the normality and homoscedasticity of the variables (i.e. Student's t-test for parametric data, and Mann-Whitney's U test for non-parametric data) to assess significant differences between seasons and habitats. To observe the joint influence of these two factors on total algal biomass, number of species (S) and diversity (H'), a two-way PerMANOVA was performed. This test used a significance level $(\mathrm{p}<0.05)$ derived from 1000 permutations, and was based on a Euclidean distance matrix.

Finally, a nonparametric Spearman's rank correlation was used to assess relationships among the species abundance and seagrass density. The PerMANOVA was obtained using the software R, version 2.15.1. The other tests were conducted using Statistica $^{\circledR}$ version 7.0.

\section{RESULTS}

The phycological community associated with these meadows consisted of 18 species in 10 families (Table 1). Most species belonged to Rhodophyta (72.2\%), followed by Chlorophyta $(22.2 \%)$ and Phaeophyceae (5.5\%). The most abundant and common species was Hypnea musciformis Lamouroux, except at SB1 where only Ulva lactuca Linnaeus was recorded (Table 2).

The majority of species were associated mainly with calcareous or rocky blocks of reefs $(50 \%)$, but some species were also found on leaves and rhizomes of $H$. wrightii (38.4\%), thalli of another alga $(8 \%)$, or as epipsammic algae (4\%) (Table 2). Epiphytic species on seagrasses almost always occurred associated with rhizomes, but tendrils of $H$. musciformis were also found attached to leaves, especially leaf tips. Besides the rhizomes, the species $U$. lactuca occurred as an epiphyte on Cryptonemia luxurians (C. Agardh) J. Agardh. The only specimen of Acantophora spicifera (M. Vahl) Borgesen was recorded epiphyting Pterocladiella caerulescens (Kützing) Santelices \& Hommersand. No significant difference was recorded for the species biomass between seasons (Table 2). Generally, the biomass of epiphytes increased according to seagrass density, unlike the epilithic/epipsammic species.

All community descriptors were higher during the dry season, with the exception of evenness in RB1, which was slightly higher during the rainy season. However, significant differences between seasons were not recorded for these variables (Table $3)$. These descriptors were significantly higher on rocky beaches (Table 4). 
Table 1. Taxonomic classification of the algal species associated with Halodule wrightii meadows on the Ceará coast in northeastern Brazil.

\begin{tabular}{|c|c|c|c|}
\hline Phylum & Family & Genus & Species \\
\hline \multirow[t]{9}{*}{ Rhodophyta } & Cystocloniaceae & Hypnea & $\begin{array}{l}\text { Hypnea musciformis (Wulfen) J.V.Lamouroux } \\
\text { Hypnea spinella (C. Agardh) Kützing }\end{array}$ \\
\hline & Pterocladiaceae & Pterocladiella & $\begin{array}{l}\text { Pterocladiella caerulescens (Kützing) Santelices \& Hommersand } \\
\text { Pterocladiella bartlettii (W. R. Taylor) Santelices }\end{array}$ \\
\hline & Gracilariaceae & Gracilaria & $\begin{array}{l}\text { Gracilaria cervicornis (Turner) J. Agardh } \\
\text { Gracilaria ornata Areschoug } \\
\text { Gracilaria spp. }\end{array}$ \\
\hline & Rhodomelaceae & Palisada & Palisada perforata (Bory de Saint-Vicent) K. W. Nam \\
\hline & & Bryothamnion & Bryothamnion seaforthii (Turner) Kützing \\
\hline & & Acanthophora & Acanthophora spicifera (M. Vahl) Borgesen \\
\hline & & Amansia & Amansia multifida J. V. Lamouroux \\
\hline & Halymeniaceae & Cryptonemia & Cryptonemia luxurians (C. Agardh) J. Agardh \\
\hline & Valoniaceae & Valonia & Valonia aegagropila $\mathrm{C}$. Agardh \\
\hline \multirow[t]{3}{*}{ Chlorophyta } & Ulvaceae & Ulva & $\begin{array}{l}\text { Ulva lactuca Linnaeus } \\
\text { Ulva sp. }\end{array}$ \\
\hline & Cladophoraceae & Cladophora & Cladophora sp. \\
\hline & Caulerpaceae & Caulerpa & Caulerpa cupressoides (West) C. Agardh \\
\hline Ochrophyta & Dictyotaceae & Dictyopteris & Dictyopteris delicatula J. V. Lamouroux \\
\hline
\end{tabular}

Table 2. Comparison between averages ( $\mathrm{t}$ or $\mathrm{U}$ tests) of the algal biomasses $\left(\mathrm{g} \mathrm{dw} \mathrm{m}^{-2}\right)$ for each site, frequency of occurrence (FO), and classification regarding the habit of species associated with Halodule wrightii meadows on the Ceará coast. Legend: $\mathrm{U}$ - sum of ranks; $\mathrm{Z}$ - critical value; $\mathrm{t}$ - critical value; $\mathrm{df}$ - degrees of freedom; $\mathrm{p}$ - significance.

\begin{tabular}{|c|c|c|c|c|c|c|}
\hline Site & Species & $\begin{array}{c}\text { Median/ } \\
\text { Mean } \\
\text { Rainy }\end{array}$ & $\begin{array}{c}\text { Median/ } \\
\text { Mean } \\
\text { Dry }\end{array}$ & Comparison between averages & FO & Habit \\
\hline Sandy Beach 1 & Ulva lactuca & 225.00 & 240.00 & $\mathrm{U}=105 ; \mathrm{Z}=-0.311 ; \mathrm{p}=0.755$ & $3.3 \%$ & epiphytic \\
\hline \multirow[t]{2}{*}{ Sandy Beach 2} & Ulva lactuca & 225.00 & 240.00 & $\mathrm{U}=105 ; \mathrm{Z}=-0.311 ; \mathrm{p}=0.755$ & $3.3 \%$ & epilithic; epiphytic \\
\hline & Hypnea musciformis & 217.50 & 247.50 & $\mathrm{U}=97.5 ; \mathrm{Z}=-0.622 ; \mathrm{p}=0.533$ & $6.6 \%$ & epiphytic \\
\hline \multirow[t]{18}{*}{ Rocky Beach 1} & Hypnea musciformis & 258.00 & 207.00 & $\mathrm{U}=87 ; \mathrm{Z}=1.057 ; \mathrm{p}=0.329$ & $33.3 \%$ & epiphytic \\
\hline & Hypnea spinella & 225.00 & 240.00 & $\mathrm{U}=105 ; \mathrm{Z}=-0.311 ; \mathrm{p}=0.374$ & $3.3 \%$ & epilithic; epiphytic \\
\hline & Pterocladiella caerulescens & 247.50 & 217.50 & $\mathrm{U}=97.5 ; \mathrm{Z}=0.622 ; \mathrm{p}=0.533$ & $6.6 \%$ & epilithic \\
\hline & Pterocladiella bartletti & 229.00 & 236.00 & $\mathrm{U}=109 ; \mathrm{z}=-0.145 ; \mathrm{p}=0.884$ & $20.0 \%$ & epilithic \\
\hline & Gracilaria cervicornis & 240.00 & 225.00 & $\mathrm{U}=105 ; \mathrm{Z}=0.311 ; \mathrm{p}=0.755$ & $3.3 \%$ & epilithic \\
\hline & Gracilaria ornata & 240.00 & 225.00 & $\mathrm{U}=105 ; \mathrm{Z}=0.311 ; \mathrm{p}=0.755$ & $3.3 \%$ & epilithic \\
\hline & Gracilaria sp. & 248.00 & 217.00 & $\mathrm{U}=97 ; \mathrm{Z}=0.624 ; \mathrm{p}=0.52$ & $13.3 \%$ & epilithic \\
\hline & Palisada perforata & 225.00 & 240.00 & $\mathrm{U}=105 ; \mathrm{Z}=-0.311 ; \mathrm{p}=0.755$ & $3.3 \%$ & epilithic \\
\hline & Bryothamnion seaforthii & 0.01 & 0.01 & $\mathrm{t}=0.204 ; \mathrm{df}=28 ; \mathrm{p}=0.839$ & $6.6 \%$ & epilithic \\
\hline & Acanthophora spicifera & 247.50 & 217.50 & $\mathrm{U}=97 ; \mathrm{Z}=0.622 ; \mathrm{p}=0.533$ & $6.6 \%$ & epiphytic (alga) \\
\hline & Amansia multifida & 240.00 & 225.00 & $\mathrm{U}=105 ; \mathrm{Z}=0.311 ; \mathrm{p}=0.755$ & $3.3 \%$ & epiphytic \\
\hline & Cryptonemia luxurians & 240.00 & 225.00 & $\mathrm{U}=105 ; \mathrm{Z}=0.311 ; \mathrm{p}=0.755$ & $3.3 \%$ & epilithic \\
\hline & Valonia aegagropila & 210.00 & 255.00 & $\mathrm{U}=90 ; \mathrm{Z}=-0.933 ; \mathrm{p}=0.350$ & $10.0 \%$ & epilithic \\
\hline & Ulva lactuca & 248.00 & 217.00 & $\mathrm{U}=97 ; \mathrm{Z}=0.642 ; \mathrm{p}=0.520$ & $13.3 \%$ & $\begin{array}{l}\text { epiphytic (alga; } H \text {. } \\
\text { wrightii) }\end{array}$ \\
\hline & Ulva sp. & 225.00 & 240.00 & $\mathrm{U}=105 ; \mathrm{Z}=-0.311 ; \mathrm{p}=0.755$ & $3.3 \%$ & epiphytic \\
\hline & Cladophora sp. & 187.50 & 277.50 & $\mathrm{U}=67.5 ; \mathrm{Z}=-1.866 ; \mathrm{p}=0.06$ & $20.0 \%$ & epilithic \\
\hline & Caulerpa cupressoides & 0.03 & 0.22 & $\mathrm{t}=-0.828 ; \mathrm{df}=28 ; \mathrm{p}=0.414$ & $6.6 \%$ & episamic \\
\hline & Dictyopteris delicatula & 247.50 & 217.50 & $\mathrm{U}=97.5 ; \mathrm{Z}=0.622 ; \mathrm{p}=0.533$ & $6.6 \%$ & epiphytic \\
\hline \multirow[t]{2}{*}{ Rocky Beach 2} & Hypnea musciformis & 0.06 & 0.02 & $\mathrm{t}=0.760 ; \mathrm{df}=28 ; \mathrm{p}=0.453$ & $26.6 \%$ & epiphytic \\
\hline & Gracilaria spp. & 0.03 & 0.21 & $\mathrm{t}=-0.841 ; \mathrm{df}=28 ; \mathrm{p}=0.407$ & $16.6 \%$ & epilithic \\
\hline
\end{tabular}

Table 3. Comparison between averages ( $\mathrm{t}$ or $\mathrm{U}$ tests) of the community descriptors of the study sites in the rainy and dry seasons. The low frequency of species on the sandy beaches prevented the calculation of some descriptors. Legend: $\mathrm{U}$ - sum of ranks; $\mathrm{Z}$ - critical value; $\mathrm{t}$ - critical value; $\mathrm{df}$ - degrees of freedom; $\mathrm{p}$ - significance; $\mathrm{S}$ number of species; N - total abundance; d - richness; J' - Pielou's evenness; H' - Shannon diversity.

\begin{tabular}{|c|c|c|c|c|c|c|c|c|c|c|c|c|c|}
\hline \multirow[t]{2}{*}{ Descriptors } & \multicolumn{3}{|c|}{ Sandy Beach 1} & \multicolumn{3}{|c|}{ Sandy Beach 2} & \multicolumn{3}{|c|}{ Rocky Beach 1} & \multicolumn{4}{|c|}{ Rocky Beach ? } \\
\hline & $\mathrm{U}$ & $\mathrm{Z}$ & $\mathrm{p}$ & $\mathrm{U}$ & $\mathrm{Z}$ & $\mathrm{p}$ & $\mathrm{t}$ & df & $\mathrm{p}$ & $\mathrm{t}$ & $\mathrm{U}$ & $\mathrm{Z}$ & $\mathrm{p}$ \\
\hline $\mathrm{S}$ & 105 & -0.3111 & 0.7557 & 90.0 & -0.9 & 0.351 & 0.676 & 28 & 0.504 & 0.992 & - & - & 0.328 \\
\hline $\mathrm{d}$ & 113 & 0 & 1 & 112.5 & 0.0 & 1.000 & -0.517 & 28 & 0.609 & - & 135.0 & -0.500 & 0.617 \\
\hline J' & 113 & 0 & 1 & 112.5 & 0.0 & 1.000 & -0.357 & 28 & 0.724 & - & 142.5 & -0.481 & 0.630 \\
\hline $\mathrm{H}^{\prime}$ & 113 & 0 & 1 & 112.5 & 0.0 & 1.000 & 0.825 & 28 & 0.417 & - & 142.5 & 0.481 & 0.630 \\
\hline
\end{tabular}


Table 4. Mean values for rocky (RB) and sandy (SB) habitats, and comparison between averages of the community descriptors. Legend: $t$ - critical value; $d f-$ degrees of freedom; $\mathrm{p}$ - significance; $\mathrm{S}$ - number of species; $\mathrm{N}$ - total abundance; d - richness; J' - Pielou's evenness; H' - Shannon diversity.

\begin{tabular}{lllccc}
\hline Descriptors & \multicolumn{1}{c}{$\begin{array}{c}\text { Mean } \\
\text { Rocky Beaches }\end{array}$} & $\begin{array}{c}\text { Mean } \\
\text { Sandy Beaches }\end{array}$ & t & df & p \\
\hline S & 1.05 & 0.067 & 5.615 & 118 & 0.000 \\
N & 1.05 & 0.067 & 5.615 & 118 & 0.000 \\
d & 79.518 & 101 & -4.04 & 118 & 0.000 \\
J' & 79.333 & 101 & -4.04 & 118 & 0.000 \\
H' & 0.234 & 0 & 3.775 & 118 & 0.000 \\
\hline
\end{tabular}

Diversity was probably the main influence on the samples dispersion in the MDS graph, which showed that samples from SB1, SB2 and RB2 were more dispersed than samples from RB1. This difference was probably related to the low abundance, diversity and qualitative similarity observed (Fig. 2).

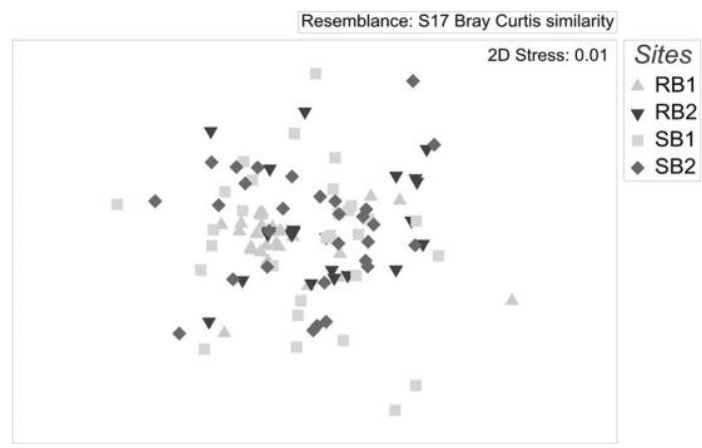

Fig. 2. Graph of Multidimensional Scaling (MDS) of the samples of the phycological communities associated with Halodule wrightii meadows on the Ceará coast in northeastern Brazil.

Although the shoot density of $H$. wrightii was higher in the dry season for sandy beaches, and in the rainy season at $\mathrm{RB} 1$, the shoot density did not differ significantly over the seasons at any of the study sites (Table 5). However, densities at RB1 were significantly higher than on the sandy beaches, in both seasons (Table 5).

The abundance of some species was significantly, although weakly, correlated with the shoot density of $H$. wrightii; these included $H$. musciformis ( $\mathrm{r}=0.383 ; \mathrm{p}=0.000)$, Pterocladiella bartletti (W. R. Taylor) Santelices $(\mathrm{r}=0.326 ; \mathrm{p}=$ 0.001), Cladophora sp. $(\mathrm{r}=0.308 ; \mathrm{p}=0.003)$, Valonia aegagrophila C. Agardh $(\mathrm{r}=0.267 ; \mathrm{p}=0.010)$, Gracilaria sp. $(\mathrm{r}=0.262 ; \mathrm{p}=0.012)$, Bryothamnion seafhortii (Turner) Kützing $(\mathrm{r}=0.221 ; \mathrm{p}=0.035)$, and Dyctiopteris delicatula J. V. Lamouroux $(\mathrm{r}=0.219 ; \mathrm{p}=$ $0.038)$. In general, the total abundance of algae $(\mathrm{r}=$ $0.614 ; \mathrm{p}=0.000)$, number of species $(\mathrm{r}=0.614 ; \mathrm{p}=$ $0.000)$, diversity $(\mathrm{r}=0.515 ; \mathrm{p}=0.000)$, richness $(\mathrm{r}=$ $0.339 ; \mathrm{p}=0.000)$, and evenness $(\mathrm{r}=0.340 ; \mathrm{p}=0.000)$ were directly and positively correlated with the shoot density of $H$. wrightii.

The PerMANOVA test corroborated these results, indicating that season did not have an individual influence on the community. This analysis indicated that habitat was the most important factor explaining significant differences in the algal assemblages $\left(F=29.4, R^{2}=0.20, p<0.001\right)$. This test also showed no interaction between habitat and season influencing the variance of the communities (Table 6).

Although the habitat has been suggested to influence these communities, the coefficient of determination $\left(\mathrm{R}^{2}\right)$ indicated that the habitat explained only $20 \%$ of the observed variance; therefore more than $85 \%$ of this variance has no explanation, considering the model adopted. This suggests that other variables (such as complex biotic and/or abiotic interactions), or even stochastic processes, affect the structure of these phycological communities.

Table 5. Mean values for Halodule wrightii density (shoots $\mathrm{m}^{-2}$ ) in the rainy and dry seasons, and comparison between averages of the study sites between seasons and also between RB1 and sandy beaches, for each season. Legend: $\mathrm{t}$ - critical value; $\mathrm{df}$ - degrees of freedom; $\mathrm{p}$ - significance.

$\begin{array}{llllll}\text { Site } & \text { Mean } & \text { Mean } & \text { Between seasons } & \text { RB1 (Dry Season) } & \text { RB1 (Rainy Season) } \\ & \text { Rainy } & \text { Dry } & & & \\ \text { RB1 } & 2866 & 3580 & \mathrm{t}=-1.557 ; \mathrm{df}=28 ; \mathrm{p}=0.130 & - & - \\ \text { SB1 } & 437 & 560 & \mathrm{t}=0.676 ; \mathrm{df}=28 ; \mathrm{p}=0.504 & \mathrm{t}=8.156 ; \mathrm{df}=28 ; \mathrm{p}=0.000^{*} & \mathrm{t}=7.781 ; \mathrm{df}=28 ; \mathrm{p}=0.000^{*} \\ \mathrm{SB} 2 & 314 & 322 & \mathrm{t}=0.058 ; \mathrm{df}=28 ; \mathrm{p}=0.953 & \mathrm{t}=9.293 ; \mathrm{df}=28 ; \mathrm{p}=0.000^{*} & \mathrm{t}=8.271 ; \mathrm{df}=28 ; \mathrm{p}=0.000^{*}\end{array}$

* Means significantly different 
Table 6. Results of PerMANOVA using habitat and season as independent variables, and total abundance, number of species and Shannon diversity $\left(H^{\prime}\right)$ as dependent variables.

$\begin{array}{lllllll} & \text { Degrees of freedom } & \text { Sum of squares } & \text { Mean squares } & \text { F. Model } & \mathrm{R}^{2} & \mathrm{p} \\ \text { Season } & 1 & 0.136 & 0.136 & 0.130 & 0.000 & 0.755 \\ \text { Habitat } & 1 & 30.650 & 30.649 & 29.390 & 0.200 & 0.000^{*} \\ \text { Season x Habitat } & 1 & 1.069 & 1.069 & 1.025 & 0.007 & 0.335 \\ \text { Residuals } & 116 & 120.970 & 1.042 & & 0.791 & \\ \text { Total } & 119 & 152.825 & & & 1.000\end{array}$

*Significant results

\section{Discussion}

The findings of this study showed that the density of $H$. wrightii was significantly greater in the rocky habitat. Consequently, seagrass density influenced the associated algal communities, whose descriptors were also significantly higher in the rocky habitat; although other probable factors related to the particular characteristics of each site apparently influenced the composition and abundance of the communities. As observed here, the patterns of algal communities on seagrasses are significantly influenced by space and time, morphological variations of the seagrasses, habitat, and particular environmental influences of the site. Seasonal variation was significantly different only in the rocky habitat, although it was higher in the dry season at almost all of the study sites, except at SB2, where the possibility of other influences should be further investigated.

The algal composition and abundance may differ with different habitats and plant parts, and may reflect morphological variation, including spatiotemporal variations, of the seagrass (LELIAERT et al., 2001; LAVERY; VANDERKLIFT, 2002). In the present study, the variations in the algal communities were related mainly to the habitat. Balata et al. (2007) observed a similar structure of epiphytic assemblages on Posidonia oceanica and the species composition at three different sites (continental coasts, offshore banks and islands). Despite the similarities, these authors suggested that the presence of rocky substrata within the meadow could be important for small-scale patterns of distribution of the epiphyte assemblages. Kuenen and Debrot (1995), studying areas with both hard and soft substrates, observed that habitat variability may increase the species richness. For the sandy habitats studied here, the one factor that appeared to influence differences in the communities was the presence or absence of rocky outcrops. According to Van Elven et al. (2004), any seagrass meadows adjacent to reefs will have diverse algae assemblages, because these may act both as sources of propagules and as modifiers of physical and nutrient conditions in adjacent areas. In the present study, the presence of rocky outcrops (SB2) may also explain, mainly, the greater abundance of algae compared with the site where these substrates are absent (SB1).
According to Dahl (1973), even in sandy habitats, hard substrata play an important role, as many algal species require hard substrates for attachment. Thus, despite the low indices of the community descriptors in the sandy habitats, the presence of algae reinforces the importance of seagrass as substrates for macroalgae settlement in environments where hard substrates are rare or absent, contributing to increase local productivity.

As described here, Bandeira (2002), studying Thalassodendron ciliatum (Forsk.) den Hartog at Inhaca Island, Mozambique, in rocky and sandy habitats observed that both the morphological characters of the meadows and epiphytic communities were significantly greater in rocky habitats. Thus, the presence of rocky substrate may lead to not only a higher diversity but also greater availability of propagules. This factor increases the probability of settlement on adjacent meadows, because, as noted by Borowitzka et al. (2006), the availability of propagules is a fundamental determinant of potential epiphyte diversity to colonize any available seagrass substrata. Confirming this hypothesis, Van Elven et al. (2004) observed higher biomass and species composition of epiphytic macroalgal assemblages on seagrasses closer to reefs. As Koch et al. (2006) added, this biotic factor is also regulated by environmental factors such as the local hydrodynamics.

Physical factors may influence the selective settlement of spores or propagules and the removal of mature specimens. According to several authors, macroalgal composition in seagrass meadows is also influenced by nutrient input, interactions between grazers, banks of propagules, and other factors (DAHL, 1973; HARLIN, 1975; PEDRINI et al., 1997; VIRNSTEIN; CARBONARA, 1985; ZIEMAN; ZIEMAN, 1989; BOROWITZKA et al., 1990; REIS; YONESHIGUE-VALENTIN, 1998; SILVA; ASMUS, 2001; BIBER et al., 2004; VAN ELVEN et al., 2004; HAYS, 2005; KOCH et al., 2006). On the rocky habitats studied here, hydrodynamic patterns appeared to be the main environmental influence. Whereas site $\mathrm{RB} 1$ is protected from waves by a natural breakwater, $\mathrm{RB} 2$ is exposed to waves that break directly on the reef where the meadow is established.

In addition to exposure to breaking waves, site RB2 also receives constant sewage discharges, 
which may have influenced the algal species composition. Several investigators have found that coastal eutrophication with increased nutrient input stimulates the growth of epiphytes, red algae and opportunistic macroalgae, which further shade and suffocate seagrasses (COUTINHO; SEELIGER 1984; ZIEMAN; ZIEMAN, 1989; PAULA et al., 2003; HAYS, 2005; BOROWITZKA et al., 2006). This is one of the reasons for seagrass declines around the world (BOROWITZKA et al., 2006). As well as the hydrodynamics, the eutrophication factor also explains the low number of species found at RB2 compared to $\mathrm{RB} 1$, as well as the exclusive presence of red-algae species and the higher incidence of one species of epiphyte at RB2. In the past, PINHEIROJOVENTINO et al. (1998) recorded very high diversity in banks of macroalgae in this site. Therefore, the algal diversity at site RB2 appears to have been negatively influenced by both the hydrodynamics and the sewage discharge.

Hydrodynamics may have also affected the shoot shedding in these $H$. wrightii meadows, because the density was lower in the rainy season. Some investigators have recorded the effects of epiphyte shedding on seagrass, as related to leaf age (SILBERSTEIN et al., 1986; SILVA; ASMUS, 2001), as these algae are often more abundant on mature shoots or leaves (ZIEMAN; ZIEMAN, 1989; BOROWITZKA et al., 1990; BANDEIRA, 2002), when the seagrass completes its life-cycle. Simultaneous fluctuations of algal biomass and the density of seagrass shoots suggest that they contribute to the plucking of the older shoots, by increasing friction with waves. In the study area, this occurs during the dry season, when the wind speeds increase (MORAIS, 1980; CASTELO BRANCO et al., 2001), influencing the coastal zone and wave height (CARVALHO et al., 2007). Although there is some evidence of environmental influences on the algal communities as presented here, these hypotheses should be further investigated throughout the annual cycle.

Apart from leaf shedding, no other negative effects of the macroalgae community on seagrass meadows were observed, as low algal biomasses were recorded. In fact, the algae and seagrasses may be benefiting each other in some respects. Positive effects of algae on seagrasses may include a reduction in both the hydrodynamic and desiccation effects during periods of exposure to air (HARLIN, 1975; PENHALE; SMITH, 1977; SAND-JENSEN; REVSBACH; JORGENSEN, 1985; SILBERSTEIN et al., 1986; BOROWITZKA et al., 1990). Furthermore, the decomposition products of algae may also be excellent sources of nutrients for seagrasses (MAZZELLA; ALBERTE, 1986). Van Elven et al. (2004) observed that inputs of decomposing drift algae and other organisms to adjacent seagrass meadows may provide nutrients that are unavailable to meadows located far from a reef. This may be one of the factors that explain the concentration of seagrass patches on the bottom adjacent to rocky outcrops at SB2.

At the same time, seagrasses may provide nutrients for algae. According to Harlin (1975), nitrate and phosphate absorbed from leaves and roots of seagrass eventually leach into adjacent water, where they are available to attached organisms before they are diluted excessively. Also according to this author, nutrient exchange with the host (seagrass) is one of the conditions for epiphyte abundance. Under conditions of low algae biomass, it is probable that these systems are only exchanging nutrients, without damage to either system.

Seagrasses and rhizophytic algae may have a symbiotic relationship (WILLIAMS, 1990; CECCHERELLI; CINELLI, 1997, 1998, 1999; PAULA et al., 2003; PERGENT et al., 2008) or may compete for nutrients (SAND-JENSEN, 1977; CECCHERELLI; CINELLI, 1997; DAVIS; FOURQUEAN, 2001) and space (TAPLIN et al., 2005; STAFFORD; BELL, 2006). However, this relationship seems to be determined by the algal biomass and the total seagrass-host biomass ratio (BOROWITZKA et al., 1990; SILVA; ASMUS, 2001). In the present study, the biomass of rhizophytic algae was low, again failing to support the hypothesis of damage to both components of the system.

Epilithic species had the most abundant and highest biomass in the present study. They are considered to be an important part of productivity in seagrass ecosystems (LEPOINT at al., 2000). Paula et al. (2003) also recorded many macroalgae associated with reefs adjacent to meadows, and reported that these algae were abundant on hard substrates, similar to the present results. These authors, however, recorded higher biomass of epipsammic species (70\%) associated with $H$. wrightii meadows in Abrolhos, northeastern Brazil. On the other hand, BIBER et al. (2004) recorded higher epiphyte biomass in relation to the other functional groups analyzed (drift algae, rhizophytic algae, psammophytic algae and epiphytic algae) on Thalassia testudinum Banks \& Soland. ex Koenig, from southern Florida (USA). Thus, the composition of species seems dependent of the conditions of surroundings environments.

In this study, epiphytic species did not participate significantly in the community composition, although the occurrence of these species is typical in other algal communities associated with seagrasses (PHILLIPS, 1982; PAULA et al., 2003). The epiphytic species were associated with rhizomes and leaves of $H$. wrightii, but the majority of the epiphytes consisted of tendrils of $H$. musciformis attached to leaf tips. Other investigators have recorded 
the preference of epiphytes for the tips of older leaves (BANDEIRA, 2002; BARRIOS; DÍAZ, 2005). BOROWITZKA et al. (1990) observed that epiphytes were more associated with stems than leaves, and few species were common on both parts, indicating that these algae prefer specific parts of the seagrass. LELIAERT et al. (2001) observed that epiphytes were better developed on the perennial stems than on the ephemeral leaves, which explained the occurrence of epiphytes on the rhizomes and longer leaves of the studied meadow.

Because of the intimate relationship with the plants, the biomass of $H$. musciformis, which was the most common and abundant macroalga of the ecosystem, varied according to the density of $H$. wrightii. Reis and Yoneshigue-Valentin (1998) also observed variations of epiphyte populations of $H$. musciformis according to the biomass of the host (Sargassum spp.). In the present study, the high frequency and the correlation between $H$. musciformis abundance and $H$. wrightii density may have influenced the dissimilarities found among the meadows, because of both the differences in occurrence of this epiphyte and the variations of the meadows.

While epiphyte blooms in seagrass meadows may have important economic and ecological consequences (CHO et al., 2003), the main relationships described in the literature for epiphytes and seagrass meadows are competition for oxygen (SAND-JENSEN; REVSBACH; JORGENSEN, 1985) and shading of the seagrasses by the algae (SANDJENSEN, 1977; SILBERSTEIN et al., 1986; BRUN et al., 2003). However, as the biomass of the epiphytes sampled here was low, they do not seem to be present in sufficient amounts to cause damage to the meadows, a situation also observed by other authors (BOROWITZKA et al., 1990; SILVA; ASMUS, 2001).

The algal community increased significantly during the dry season, similarly to the results of Plus et al. (2001). These authors observed increases in epiphyte biomass on Zostera noltii Hornem during the summer, on the French Mediterranean coast, but they did not relate these increases to changes in the seagrass. In an area adjacent to seagrasses, Paula et al. (2003) observed, however, that diversity and evenness were significantly higher during the rainy season.

In conclusion, the results obtained here indicate that the phycological community varied mainly according to the density of $H$. wrightii, independently of particular features of the site, although the habitat and other environmental influences at each site (i.e. hydrodynamics and sewage at the rocky beaches, and presence/absence of rocky outcrops at the sandy beaches) may have also influenced the macroalgae composition and diversity.
Thus, the composition of the phycological community depends on a number of biotic and abiotic factors, which may be related to the morphological characters of the host-seagrass system, habit of the species, and environmental characters of each site. Ruling out possibilities of opposing relationships and taking into account the leading presence of these species, the ecological relationship suggested for this algaeseagrass complex is mutualism between the two cohabiting systems.

\section{AKNOWLEDGEMENTS}

The first author is grateful to the Coordenação de Aperfeiçoamento de Pessoal de Nível Superior (Capes) for the award of a doctoral scholarship.

\section{REFERENCES}

ALBRECHT, A. S. Soft bottom versus hard rock: community ecology of macroalgae on intertidal mussel beds in the Wadden Sea. J. Exp. Mar. Biol. Ecol., v. 229, n.1, p. 85-109, 1998.

BALATA, D.; NESTI, U.; PIAZZI, L.; CINELLI, F. Patterns of spatial variability of seagrass epiphytes in the northwest Mediterranean Sea. Mar. Biol., v. 151, n. 6, p. 2025-2035, 2007.

BANDEIRA, S. O. Leaf production rates of Thalassodendron ciliatum from rocky and sandy habitats. Aquat. Bot., v. 72, n, 1, p. 13-24, 2002.

BARRIOS, J.; DÍAZ, O. Algas epífitas de Thalassia testudinum en el Parque Nacional Mochima, Venezuela. Bol. Cent. Invest. Biol., v. 39, n. 1, p. 1-14, 2005.

BIBER, P. D.; HARWELL, M. A.; CROPPER Jr., W. P. Modeling the dynamics of three functional groups of macroalgae in tropical seagrass habitats. Ecol. Modell., v. 175 , p. 25-54, 2004.

BOROWITZKA, M. A.; LAVERY, P. S.; VAN KEULEN, M. Epiphytes of seagrasses. In: LARKUM, A. W. D.; ORTH, R. J.; DUARTE. C. M. (Eds.). Seagrasses: biology, ecology and conservation. Dordrecht: Springer, 2006. p. 446-461.

BOROWITZKA, M. A.; LETHBRIDGE, R. C. Seagrass epiphytes. In: LARKUM, A. W. D.; MCCOMB, A. J.; SHEPHERD, S. A. (Eds.). Biology of seagrasses: a treatise on the biology of seagrases with special reference to the Australian region. Amsterdam: Elsevier, 1989. p. 458-499. (Aquatic plant studies; 2).

BOROWITZKA, M. A.; LETHBRIDGE, R. C.; CHARLTON, L. Species richness, spatial distribution and colonization pattern of algal and invertebrate epiphytes on the seagrass Amphibolis griffithii. Mar. Ecol.: Prog. Ser., v. 64, p. 281-291, 1990.

BURDICK, D. M.; KENDRICK, G. A. Standards for seagrass collection, identification and sample design. In: SHORT, F. T.; COLES, R. G. (Eds.). Global seagrass research methods. Amsterdam: London: Elsevier, 2001. p. $79-100$ 
BRUN, F. G.; VERGARA, J. J.; NAVARRO, G.; HERNANDEZ, I.; PEREZ-LLORENS, J. L. Effect of shading by Ulva rígidacanopies on growth and carbon balance of the seagrass Zostera noltii. Mar. Ecol.: Prog. Ser., v. 265, p. 85-96, 2003.

CARVALHO, M. A.; MAIA, L. P.; DOMINGUEZ, J. M. L. A deriva e o transporte litorâneo de sedimentos no trecho entre Cumbuco e Matões - costa noroeste do estado do Ceará. Arq. Cienc. Mar., v. 40, n. 1, p. 43-51, 2007.

CASTELO BRANCO, M. P. N.; LEHUGEUR, L. G. O.; FREIRE, G. S. S. Transporte eólico nas praias de Pontal do Maceió, município de Fortim, e Canoa Quebrada, município de Aracati, Estado do Ceará, Brasil. Arq. Cienc. Mar., v. 34. p. 99-105, 2001

CECCHERELLI, G.; CINELLI, F. Short-term effects of nutrient enrichment of the sediment and interactions between the seagrass Cymodocea nodosa and the introduced green alga Caulerpa taxifolia in a Mediterranean bay. J. Exp. Mar. Biol. Ecol., v. 217, n. 2, p. 165-177, 1997.

CECCHERELLI, G.; CINELLI, F. Habitat effect on spatiotemporal variability of size and density of the introduced alga Caulerpa taxifolia. Mar. Ecol.: Progr. Ser., v. 163, p. 289-294, 1998.

CECCHERELLI, G.; CINELLI, F. Effects of Posidonia oceanica canopy on Caulerpa taxifolia size in a northwestern Mediterranean bay. J. Exp. Mar. Biol. Ecol., v. 240, n. 1, p. 19-36, 1999.

CHO, T. O.; FREDERICQ, S.; YATES, K. K. Characterization of macroalgal epiphytes on Thalassia testudinum in Tampa bay, Florida. J. Phycol., v. 38, suppl. 1, p. 4, 2002.

COUTINHO, R.; SEELIGER, U. The horizontal distribution of the benthic algal flora in the Patos Lagoon Estuary, Brazil, in relation to salinity, substratum and wave exposure. J. Exp. Mar. Biol. Ecol., v. 80, n. 3, p. 247 257, 1984.

DAHL, A. L. Benthic algal ecology in a deep reef and sand habitat of Puerto Rico. Bot. Mar., v. 16, n. 3, p. 171-175, 1973.

HARLIN, M. M. Epiphyte-host relations in seagrass communities. Aquat. Bot., v. 1, p. 125-131, 1975.

HAY, M. E. Herbivory, algal distribution, and the maintenance of between-habitat diversity on a tropical fringing reef. Am. Nat., v. 18, n. 4, p. 520-540, 1981.

HAYS, C. G. Effect of nutrient availability, grazer assemblage and seagrass source population on the interaction between Thalassia testudinum (turtle grass) and its algal epiphytes. J. Exp. Mar. Biol. Ecol., v. 314, n. 1, p. 53-68, 2005.

KOCH, E. W.; ACKERMAN, J. D.; VERDUIN, J.; VAN KEULEN, M. Fluid dynamics in seagrass ecologyfrom molecules to ecosystems. In: LARKUM, A. W. D.; ORTH, R. J.; DUARTE. C. M. (Eds.). Seagrasses: biology, ecology and conservation. Dordrecht: Springer, 2006. p. 195-225.

KÖPPEN, W. Climatologia: con un estudio de los climas de la tierra. México: Fondo de Cultura Econômica, 1948. 479 p.

KUENEN, M. M. C. E.; DEBROT, A. O. A quantitative study of the seagrass and algal meadows of the Spanse
Water, Curaçao, the Netherlands Antilles. Aquat. Bot., v. 51, n. 3/4, p. 291-310, 1995.

LAVERY, P. S.; VANDERKLIFT, M. A. A comparison of spatial and temporal patterns in epiphytic macroalgal assemblages of the seagrasses Amphibolis griffithii and Posidonia coriacea. Mar. Ecol.: Prog. Ser., v. 236, p. 99-112, 2002

LEE, S. Y.; FONG, C. W.; WU, R. S. S. The effects of seagrass (Zostera japonica) canopy structure on associated fauna: a study using artificial seagrass units and sampling of natural beds. J. Exp. Mar. Biol. Ecol., v. 259 , n. 1, p. 23-50, 2001

LELIAERT, F.; VANREUSEL, W.; DE CLERCK, O.; COPPEJANS, E. Epiphytes on the seagrasses of Zanzibar Island (Tanzania), floristic and ecological aspects. Belg. J. Bot., v. 134, n. 1, p. 3-20, 2001.

LEPOINT, G.; NYSSEN, F.; GOBERT, S.; DAUBY, P.; BOUQUEGNEAU, J. -M. Relative impact of a seagrass bed and its adjacent epilithic algal community in consumer diets. Mar. Biol., v. 136, n. 3, p. 513-158, 2000.

MARBÀ, N.; DUARTE, C. M.; ALEXANDRE, A.; CABAÇO, S. How do seagrasses grow and spread. In: BORUM, J.; DUARTE, C. M.; KRAUSE-JENSEN, D.; GREVE, T. M. (Eds.). European seagrasses: an introduction to monitoring and management. [S.1.]: M\&MS PROJECT, 2004. p. 11-18.

MAZZELLA, L.; ALBERTE, R. S. Light adaptation and the role of autotrophic epiphytes in primary production of the temperate seagrass Zostera marina L. J. Exp. Mar. Biol. Ecol., v. 100, p. 165-180, 1986.

MORAIS, J. O. Aspectos do transporte de sedimentos no litoral do município de Fortaleza, estado do Ceará, Brasil. Arq. Cienc. Mar., v. 20, n. 1/2, p.71-100, 1980.

MORAIS, J. O.; FREIRE, G. S. S.; PINHEIRO, L. S.; SOUZA, M. J. N.; CARVALHO, A. M.; PESSOA, P. R. S.; OLIVEIRA, S. H. M. Ceará. In: MUEHE, D. (Org.). Erosão e progradação do litoral brasileiro. Brasília: Ministério do Meio Ambiente, 2006, p. 132-154.

NORKKO, J.; BONSDORFF, E.; NORKKO, A. Drifting algal mats as an alternative habitat for benthic invertebrates: species specific responses to a transient resource. J. Exp. Mar. Biol. Ecol., v. 248, n. 1, p. 79$104,2000$.

PAUlA, A. F.; FIGUEIREDO, M. A. O.; CREED, J. C. Structure of the macroalgal community associated with the seagrass Halodule wrightii ascherson in the Abrolhos Marine National Park, Brazil. Bot. Mar., v. 46, n. 5, p. 413-424, 2003.

PEDRINI, A. G.; LIMA, D. S.; PEREIRA-FILHO, O.; MUSQUIM, V. S.; DE-PAULA, J. C. Algas bentônicas da Lagoa de Marapendi, Rio do Janeiro, RJ, Brasil. Albertoa, v. 4, n. 18, p. 233-244, 1997.

PEDRINI, A. G.; SILVEIRA, I. C. A. Composição taxonômica e estimativa da biomassa das macroalgas epífitas em Ruppia marítima L. na Lagoa de Marapendi. Rio de Janeiro, RJ, Brasil. Atas Soc. Bot. Brasil., v. 3, n. 6, p. 45-60, 1985.

PENHALE, P. A.; SMITH, W. O. Excretion of dissolved organic carbon by eelgrass (Zostera marina) and its epiphytes. Limnol. Oceanogr., v. 22, n. 3, p. 400-407, 1977. 
PERGENT, G.; BOUDOURESQUE, C. -F.; DUMAY, O.; PERGENT-MARTINI, C.; WYLLIE-ECHEVERRIA, S. Competition between the invasive macrophyte Caulerpa taxifolia and the seagrass Posidonia oceanica: contrasting strategies. BMC Ecol., v.8, p.1-20, 2008.

PHILLIPS, R. C.; VADAS, R.L.; OGDEN, N. The marine algae and seagrasses of the Miskito Bank, Nigaragua. Aquat. Bot., v. 13, p. 187-195, 1982.

PINHEIRO-JOVENTINO, F.; DANTAS, N. P.; MARASCHIN, C. D. H. Distribuição de algas marinhas no litoral de Fortaleza, Ceará, Brasil. Arq. Cienc. Mar., v. 31, n. 1/2, p. 29-40, 1998.

PLUS, M.; DESLOUS-PAOLI, J. M.; AUBY, I.; DAGAULT, F. Factors influencing primary production of seagrass beds (Zostera noltii Hornem) in the Thau lagoon (French Mediterranean coast). J. Exp. Mar. Biol. Ecol., v. 259, n. 1, p. 63-84, 2001.

REIS, R. P; YONESHIGUE-VALENTIN, Y. Variação espaço-temporal de populações de Hypnea musciformis (RHODOPHYTA, GIGARTINALES) na Baía de Sepetiba e Armação dos Búzios, RJ, Brasil. Acta Bot. Bras., v. 12, n.3, p.465-483, 1998.

ROSA, L. C.; BEMVENUTI, C. E. Seria a macrofauna bentônica de fundos não consolidados influenciada pelo aumento na complexidade estrutural do habitat? O caso do estuário da Lagoa dos Patos. Braz. J. Aquat. Sci. Technol., v. 11, n. 1, p. 51-56, 2007.

SAND-JENSEN, K. Effect of epiphytes on eelgrass photosynthesis. Aquat. Bot., v. 3, p. 55-63, 1977.

SAND-JENSEN, K.; REVSBACH, N. P.; JORGENSEN, B. B. Microprofiles of oxygen in epiphyte communities on submerged macrophytes. Mar. Biol., v. 89, n. 1, p. 5562, 1985 .

SILBERSTEIN, K.; CHIFFINGS, A. W.; McCOMB, A. J. The loss of seagrass in cockburn sound, Western Australia. III. The effect of epiphytes on productivity of Posidonia australis Hook. F. Aquat. Bot., v. 24, n. 4, p. 355-371, 1986.

SILVA, E. T.; ASMUS, M. L. A dynamic simulation model of the widgeon grass Ruppia marítima and its epiphytes in the estuary of the Patos Lagoon, RS, Brazil. Ecol. Modell., v. 137, n. 2/3, p. 161-179, 2001.
SILVA, R. L.; PEREIRA, S. M. B.; OLIVEIRA-FILHO, E. C. D.; ESTON, V. R. Structure of a bed of Gracilaria spp. (Rhodophyta) in northeastern Brazil. Bot. Mar., v. 30, n. 6, p. 517-523, 1987.

STAFFORD, N. B.; BELL, S. S. Space competition between seagrass and Caulerpa prolifera (Forsskaal) Lamouroux following simulated disturbances in Lassing Park, FL. J. Exp. Mar. Biol. Ecol., v. 333, n. 1, p. 49-57, 2006.

TAPLIN, K. A.; IRLANDI, E. A.; RAVES, R. Interference between the macroalga Caulerpa prolifera and the seagrass Halodule wrightii. Aquat. Bot., v. 83, n. 3, p. 175-186, 2005.

VAN ELVEN, B. R.; LAVERY, P. S.; KENDRICK, G. A. Reefs as contributors to diversity of epiphytic macroalgae assemblages in seagrass meadows. Mar. Ecol.: Prog. Ser., v. 276, p. 71-83, 2004.

VIRNSTEIN, R. W.; CARBONARA, P. A. Seasonal abundance and distribution of drift algae and seagrasses in the mid-Indian River Lagoon, Florida. Aquat. Bot., v. 23, n. 1, p. 67-82, 1985.

WILLIAMS, S. L. Experimental studies of Caribbean seagrass bed development. Ecol Monogr., v. 60, n. 4, p. 449-469, 1990.

WILLIAMS, S. L.; HECK, K. L. Seagrass community ecology. In: BERTNESS, M. D.; GAINES, S. D.; HAY, M. E. (Eds.). Marine community ecology. Sunderland: Sinauer Associates, 2001. p. 317-338.

ZIEMAN, J. C.; ZIEMAN, R. T. The ecology of the seagrass meadows of the west coast of Florida: a community profile. Charlottesville: U.S. Department of the Interior Fish and Wildlife Service Research and Development, 1989. 155 p. (U.S. Fish and Wildlife Service Biological Report, 85).

(Manuscript received 13 November 2012; revised 24 November 2013; accepted 09 December 2013) 